\title{
Naringin Attenuates Aluminum Induced Cognitive Deficits in Rats
}

\section{Orsu Prabhakar}

GITAM Institute of Pharmacy, GITAM (Deemed to be University), Visakhapatnam, Andhra Pradesh, INDIA.

\begin{abstract}
Aim: The exposure of aluminum for longer period in brain can lead to impaired cognition and behavioral changes. The present study was aimed to investigate the aluminum induced cognitive deficits and possible protective outcomes of naringin. Materials and Methods: Aluminum chloride in a dose of $100 \mathrm{mg} / \mathrm{kg}$ i.p was employed for 60 days to induce cognitive deficits in Westar rats. The animals were divided into groups each group contain six animals, as normal, aluminum treated, naringin treated $(25,50$, $100 \mathrm{mg} / \mathrm{kg}$ ). These animals were used to estimate behavioral characters such as Open field, eight arm radial maze, Morris water maze and Rota-rod tests and also used to assess the biochemical parameters such as acetylcholine esterase activity, malondialdehyde, superoxide dismutase and catalase. Results: Aluminum intoxicated rats showed significantly reduced exploratory and spontaneous locomotors activities in open field test and significant impairment in working and learning memory assessed by Morris water maze and radial arm maze tests. It also significantly increased acetylcholine esterase activity and malondialdehyde. The superoxide dismutase and catalase were also decreased significantly. Naringin was given (25, 50 and $100 \mathrm{mg} / \mathrm{kg} P O$ ) to the aluminum intoxicated rats for a period of 30 days. The naringin treatment has shown significant improvements in spontaneous locomotors and exploratory activities and memory performance tasks of rats. Conclusion: The oxidative stress (reduced lipid peroxidation, restored reduced superoxide dismutase and catalase) and acetylcholine esterase activity were significantly decreased in the naringin group. Thus, these findings supported that naringin has showed potential neuroprotection against aluminum induced oxidative stress and cognitive deficit.
\end{abstract}

Key words: Acetylcholine esterase, Aluminum, Alzheimer, Cognitive impairment, Oxidative stress, Naringin.

\section{INTRODUCTION}

Aluminum (Al) is well known and most abundant metal in nature. It is a constituent in drinking water, medicines and cooking utensils. It can be accessed into the human body through the water, food and air. $\mathrm{Al}$ can produce pathological and clinical features which were in resemblance to those features observed in dementia. In many cases the patients with dementia showed $\mathrm{Al}$ traces in their brains which were deposited in the neurofibrillary tangles and senile plaques of neurons. Several researchers also demonstrated the $\mathrm{Al}$ intoxication in experimental animals and humans cause neurotoxicity and cognitive deficits. ${ }^{1-4}$ Therefore, in this study $\mathrm{Al}$ intoxication in animals was considered as experimental model. Generally, memory process and learning process in the brain are maintained by the cholinergic system. In dementia brain, the cholinergic system is one of the key area which is affected mostly in brain especially the projections from basal forebrain to cortex and hippocampus.

The superoxide semi-reduced radical ions formed due to $\mathrm{Al}$ intoxication can cause cognitive deficiency and dementia in the brain, ${ }^{5}$ suggesting the influence of $\mathrm{Al}$ and superoxide radical interactions in
Submission Date: 01-11-2019; Revision Date: 07-04-2020; Accepted Date: 12-05-2020

DOI: 10.5530/ijper.54.3.117 Correspondence: Dr. Orsu Prabhakar Assistant Professor, Department of Pharmacology, GITAM Institute of Pharmacy, GITAM (Deemed to be University), Visakhapatnam-530045, Andhra Pradesh, INDIA. Phone: +919912988579 E-mail: prabhakar.orsu@ gitam.edu

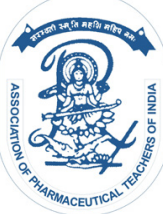

www.ijper.org 
the promotion of superoxide associated biological oxidation. ${ }^{6,7}$ Furthermore, the exposure of $\mathrm{Al}$ can result in its CNS accumulation and induces the reactive oxygen species (ROS) formation. This results in increased lipid peroxidation and altering the brain oxidative mechanisms that might promote $\beta$-amyloid peptide deposition and formation.

$\mathrm{Al}$ chronic exposure can induce cholinergic terminals degeneration in the cortical areas and depletion of cells in is cortex and hippocampus. In the cingulated bundle, more $\mathrm{Al}$ accumulation was found and thereby induces learning deficits. ${ }^{8}$ The expression of antioxidant enzymes such as superoxide dismutase (SOD) and catalase (CAT) are induced by the exposure of $\mathrm{Al}$ and associated oxidative stress. ${ }^{910}$ Thus, $\mathrm{Al}$ promotes aggregation of insoluble amyloid-b-protein, hyperphosphorylated tau-protein and causes more pathological changes in cholinergic system. ${ }^{11,12}$ This might be the possible way by which aluminum involving in pathological process of dementia.

In the management of dementia, acetylcholinesterase inhibition and oxidative stress inhibition are the important therapeutic strategies. There are very good number of pragmatic evidences supporting that the plant-derived antioxidants, especially flavonoids are useful for the control of neurodegenerative disease. Naringin is one of the flavonoids which has been reported as a potent antioxidant, anti-inflammatory and neuroprotective agent. ${ }^{13-16}$ Therefore, this study was involved to explore the behavioral and biochemical changes of $\mathrm{Al}$ intoxicated brain and the protective effects of naringin. Open field, Eight arm radial maze, Morris water maze and Rota-rod tests were selected to evaluate the behavioral characters.

\section{MATERIALS AND METHODS}

\section{Animals}

Either sex Westar rats (180-210 g) were obtained from the NIN, Hyderabad, Telangana, India. Animals were maintained in an ambient temperature $\left(24 \pm 1^{\circ} \mathrm{C}\right)$ colony room under a 12/12-hr light/dark cycle. Animals were taken care in compliance with the CPCSEA guidelines, New Delhi and experiments were conducted by the approval of the Institutional Animal Ethics Committee, GITAM Deemed to University, Visakhapatnam.

\section{Experimental Design}

\section{Drugs and Chemicals}

Aluminum chloride (CDH, India), Thiopentone sodium (Neon-labs, Mumbai), Thiobarbituric acid (Merck India), 1,1,3,3-tetraethoxy-propane (arrow India), nitroblue tetrazolium (Merck India), Nicotinamide adenine dinucleotide phosphate reduced form (SigmaAldrich, India), Naringin (Sigma-Aldrich India), All other reagents and chemicals used in the experiment were analytical grade.

\section{Treatment schedule}

$\mathrm{Alcl}_{3}$ was administered intraperitonially at a dose of $100 \mathrm{mg} / \mathrm{kg} /$ day for 60 days. This was followed by oral administration of naringin at different doses $(25,50$ and $100 \mathrm{mg} / \mathrm{kg} /$ day) for 30 days. At the beginning of experiment, before aluminum or naringin administration the animals were weighed followed by weighing on daily basis until the end of behavioral tests.

\section{Experimental design}

Group I: Normal, Group II: Al+S, Group III: $\mathrm{Al}+$ NG25 (Naringin $25 \mathrm{mg} / \mathrm{kg}$ treated), Group IV: Al+ NG50 (Naringin $50 \mathrm{mg} / \mathrm{kg}$ treated), Group V: $\mathrm{Al}+$ NG100 (Naringin $100 \mathrm{mg} / \mathrm{kg}$ treated), Group VI: Al+ Donepezil (Donepezil treated $0.75 \mathrm{mg} / \mathrm{kg}$ ) with each group consisting of 6 animals. This study was conducted for a period of 90 days.

\section{Biochemical Assessments}

After completion of behavioral tests the animals were sacrificed by cervical dislocation. The rat's brains were removed and rinsed in ice-cold isotonic saline solution. Further, the brain tissues were homogenized with icecold $150 \mathrm{mM} \mathrm{KCl}$. The obtained homogenate $(10 \%$ $\mathrm{w} / \mathrm{v}$ ) was then centrifuged at 11,000 rpm for $15 \mathrm{~min}$. The supernatants of centrifuged tissues were used for biochemical estimations.

\section{Estimation of Acetylcholinesterase (AChE) activity}

According to the standard method of Ellman et al. the activity of acetylcholinesterase was measured in the centrifuged brain tissue supernant. ${ }^{17}$ The absorbance changes were recorded at $412 \mathrm{~nm}$ by UV spectrophotometer and the findings were expressed in $\mu$ moles of acetylcholine iodide hydrolyzed $/ \mathrm{min} / \mathrm{mg}$ protein.

\section{Estimation of oxidative stress markers}

The isolated brain tissues were used for measuring oxidative stress parameters in it, such as malondialdehyde (MDA), superoxide dismutase (SOD) and catalase.

The lipid peroxidation concentration (MDA) in the serum was determined by the Ohkawa et al. MDA levels were articulated in $\mathrm{nMol} /$ lit. $^{18} \mathrm{SOD}$ levels were measured by the superoxide radicals which are generated by xanthine and xanthine oxidase, using Kakkar et al. In this method, with 2-(4-iodophenyl)-3-(4-nitro phenol-s- 
phenyl tetrazolium) chloride to form a red formazon dye. SOD activity is then measured by the degree of inhibition of this reaction. ${ }^{19}$

Catalse concentration was measured by the degradation rate of $\mathrm{H}_{2} \mathrm{O}_{2}$ using Aebi's method. The rate of $\mathrm{H}_{2} \mathrm{O}_{2}$ desertion was observed spectrophotometrically at $230 \mathrm{~nm}$. The assay consisted of $50 \mu \mathrm{l} 1 \mathrm{M}$ Tris HCI buffer ( $\mathrm{pH} 8$ ), $930 \mu \mathrm{l} 10 \mathrm{mM} \mathrm{H} 2 \mathrm{O} 2,930 \mu \mathrm{l}$ deionized water and $20 \mu \mathrm{l}$ serum sample. One unit of Catalase activity is defined as the amount of enzyme causing about $90 \%$ destruction of the substrate in $1 \mathrm{~min}$ in a volume of $1 \mathrm{ml}$. Catalase activity in the serum was expressed as Unit $/ \mathrm{ml} .^{20}$

\section{Behavioral tests}

\section{Open field method}

The method followed was described by Abdel-Aal et al. 2011. In brief, the equipment consisted of a square wooden box in which the base was divided into 49 squares. Individual animal was tested for $5 \mathrm{~min}$ in the instrument. The number of squares crossed by the animal gives the locomotor activity. The rearing movements of the animals were assessed by vertical activity.

\section{Morris water maze test}

This test was carried as described in Abdel-Aal et al. 2011. The apparatus consisted of a circular stainless steel tank. This tank was divided by 4 quadrants and fixed 4 points on its perimeter. This test assesses the nootropic activity in terms of latency period. The latency time recorded in terms of time taken for the animal to reach the hidden platform.

\section{Radial arm Maze test}

In an eight-arm maze, this test was conducted. This method was executed according to Abdel-Aal et al. 2011. The rats entering at least half of the length of the arm were recorded as arm choices. The rats choosing all baited arms or spent $10 \mathrm{~min}$ was noted as completion of task. Rats were trained twice daily for 6 days/week upto 2.5 weeks i.e. each rat received 30 trials. The number of entries to unbaited arms or re-entering a baited arm was noted as errors. In every trail, the time required to complete the task was also noted.

\section{Rota-rod test}

On the rota-rod apparatus rats were placed for 5 min. The time latency was noted in terms of motor coordination and integrity which was assessed by the time required to fell from the rota-rod. This method was described by Abdel-Aal et al. 2011.

\section{Statistical analysis}

All values of experiment results were represented as mean \pm S.E.M and analyzed by one-way ANOVA or two way ANOVA by the Bonferroni test, $P \leq 0.005$ was considered to be significant.

\section{RESULTS}

\section{Effect of naringin on open field test Horizontal (crossing) activity}

The effect of naringin (25, 50 and $100 \mathrm{mg} / \mathrm{kg}$ ) on horizontal crossing activity based on number of crossings was demonstrated in Figure 1A. One way ANOVA has revealed the significant difference among the all experiment groups in terms of number of crossings $[\mathrm{F}(6,52)=13.41, P \leq 0.05]$. The number of crossings were significantly reduced in $\mathrm{Al}+\mathrm{S}$ group relative to control $[\mathrm{t}=8.14, P \leq 0.05]$. In contrast, increased number of crossings was observed in naringin treated groups significantly than $\mathrm{Al}+\mathrm{S}$ group.

\section{Rearing activity}

Among all experiment groups One-way ANOVA showed significant differences in the number of rearing $[\mathrm{F}(6,52)=10.82, P \leq 0.05]$. The number of rearings were decreased significantly in $\mathrm{Al}+\mathrm{S}$ group with relative to control $[\mathrm{t}=5.53, P \leq 0.05]$. However, naringin $(25,50$ and $100 \mathrm{mg} / \mathrm{kg}$ ) treated groups were shown increased number of rearings significantly rather than the $\mathrm{Al}+\mathrm{S}$ group. Results were showed in the Figure 1B.

\section{Role of naringin on morris water maze test}

The effect of naringin $(25,50$ and $100 \mathrm{mg} / \mathrm{kg}$ ) on latency period to find the platform was demonstrated in Table 1. In comparison with control group, there

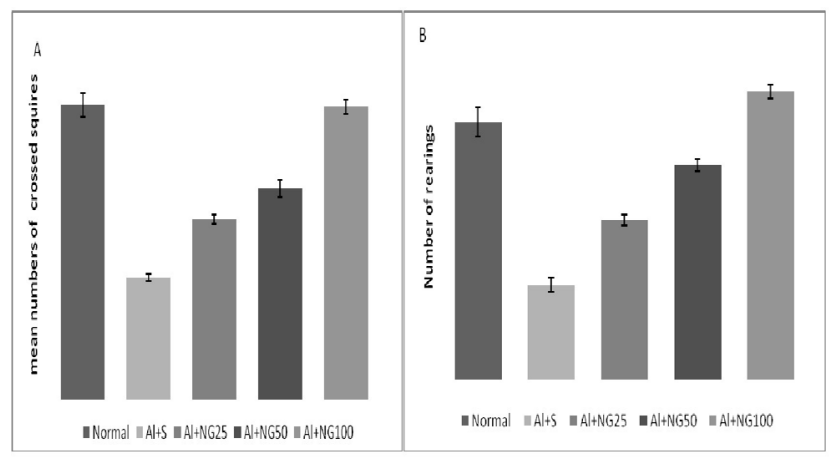

Figure 1: Effect of Narigin $(25,50,100 \mathrm{mg} / \mathrm{kg})$ on crossings (A), the number of rearings $(B)$ against Aluminum intoxication rats.

All values expressed mean \pm S.E.M. $P \leq 0.05, \mathrm{a}=\mathrm{Al}+\mathrm{S}$ Vs Normal, $\mathrm{b}=\mathrm{Al}+\mathrm{S}$ Vs $\mathrm{A}+\mathrm{NG} 25, \mathrm{C}=\mathrm{A}+\mathrm{NG} 25 \mathrm{Vs} \mathrm{Al}+\mathrm{S}, \mathrm{d}=\mathrm{Al}+\mathrm{NG} 100 \mathrm{Vs} \mathrm{Al}+\mathrm{S} . \mathrm{NG}=$ Naringin, $\mathrm{S}=$ Saline, $\mathrm{Al}=$ Aluminum 
Table 1: Effect of Naringin $(25,50,100 \mathrm{mg} / \mathrm{kg})$ on the time (seconds) in Morris water maze test against Aluminum intoxication rats.

\begin{tabular}{|c|c|c|c|c|c|}
\hline & Day 1 & Day 2 & Day 3 & Day 4 & Day 5 \\
\hline Normal & $46.0 \pm 0.856$ & $32.7 \pm 0.802$ & $24.8 \pm 0.654$ & $23.7 \pm 0.843$ & $19.5 \pm 0.612$ \\
\hline Al+S & $64.5 \pm 1.522$ & $56.0 \pm 0.683^{\mathrm{a}}$ & $53.5 \pm 0.847^{\mathrm{a}}$ & $50.7 \pm 1.085^{\mathrm{a}}$ & $50.7 \pm 1.085^{\mathrm{a}}$ \\
\hline Al+NG25 & $57.5 \pm 0.619$ & $45.17 \pm 0.477^{\mathrm{b}}$ & $41.5 \pm 0.428^{\mathrm{b}}$ & $38.17 \pm 0.307^{\mathrm{b}}$ & $34.17 \pm 0.703^{\mathrm{b}}$ \\
\hline Al+NG50 & $52.2 \pm 0.654$ & $42.2 \pm 0.703^{\mathrm{b}}$ & $33.5 \pm 0.671^{\mathrm{b}}$ & $31.2 \pm 0.601^{\mathrm{b}}$ & $29.8 \pm 0.703^{\mathrm{b}}$ \\
\hline Al+NG100 & $45.7 \pm 0.843^{\mathrm{b}}$ & $35.7 \pm 0.558^{\mathrm{b}}$ & $29.3 \pm 0.715^{\mathrm{b}}$ & $24.5 \pm 0.428^{\mathrm{b}}$ & $18.5 \pm 0.619^{\mathrm{b}}$ \\
\hline
\end{tabular}

All values expressed mean \pm S.E.M. $P \leq 0.005, a=A l+S$ Vs Normal, $b=A l+N G 25$ Vs Al+S, Al+NG5o Vs Al+s and Al+NG100 Vs Al+S. NG =Naringin, $S=S a l i n e, A l=A l u m i n u m$

Table 2: Effects of Naringin (25, 50 and100 mg/kg) on the mean number of errors in radial arm maze against
\begin{tabular}{|c|c|c|c|c|} 
aluminum intoxication. & Al+NG50 & Al+NG100 \\
\hline Normal & $\mathrm{Al}+\mathrm{S}$ & $\mathrm{Al}+\mathrm{NG} 25$ & $2.83 \pm 0.17^{\mathrm{c}}$ & $1.83 \pm 0.17^{\mathrm{d}}$ \\
\hline $3.67 \pm 0.21$ & $6 \pm 0.26^{\mathrm{a}}$ & $3.83 \pm 0.17^{\mathrm{b}}$ & $2.65 \pm 0.17^{\mathrm{c}}$ & $1.86 \pm 0.15^{\mathrm{d}}$ \\
\hline $2.98 \pm 0.19$ & $5.24 \pm 0.24^{\mathrm{a}}$ & $2.89 \pm 0.19^{\mathrm{b}}$ & $2.05 \pm 0.17^{\mathrm{c}}$ & $1.79 \pm 0.25^{\mathrm{d}}$ \\
\hline $3.12 \pm 0.21$ & $5.59 \pm 0.20^{\mathrm{a}}$ & $2.16 \pm 0.15^{\mathrm{b}}$ & $1.96 \pm 0.25^{\mathrm{c}}$ & $1.89 \pm 0.12^{\mathrm{d}}$ \\
\hline $2.96 \pm 0.19$ & $4.94 \pm 0.96^{\mathrm{a}}$ & $2.25 \pm 0.16^{\mathrm{b}}$ & $1.89 \pm 0.32^{\mathrm{c}}$ & $1.29 \pm 0.13^{\mathrm{d}}$ \\
\hline $2.54 \pm 0.15$ & $4.52 \pm 0.25^{\mathrm{a}}$ & $2.21 \pm 0.19^{\mathrm{b}}$ & \\
\hline
\end{tabular}

All values expressed mean \pm S.E.M. $P \leq 0.05, a=A l+S$ Vs Normal, $b=A l+S$ vs $A+N G 25, c=A l+N G 50$ Vs Al+S, $d=A l+N G 100$ Vs Al+S. NG Indicate Naringin, $S=S a l i n e, A l=A l u m i n u m$

was significant increased latency period in finding the platform in the Al+ S treated group $[\mathrm{F}(1,60)=64.5$, $P \geq 0.05]$, significant differences were obtained in day 2 $[\mathrm{t}=6.21, P \leq 0.05], 3[\mathrm{t}=6.71, P \leq 0.05], 4[\mathrm{t}=9.21 P \leq 0.05]$ and $5[\mathrm{t}=8.22, P \leq 0.05]$. Whereas, naringin treated group showed a significant decrease in time latency when compared to $\mathrm{Al}+\mathrm{S}$ treated group.

\section{Role of naringin on Radial arm maze test Reference memory}

The effects of naringin on reference memory based on the number of errors using radial arm maze test was demonstrated in Table 2. The results showed a significant increased number of errors among the $\mathrm{Al}+\mathrm{S}$ treated groups when compared to control group [factor aluminum treatment; $\mathrm{F}(1,56)=65.06, P \leq 0.05$ ] in blocks $2[\mathrm{t}=.4 .73, P \leq 0.05], 3[\mathrm{t}=5.07, P \leq 0.05], 4[\mathrm{t}=7.18$, $P \leq 0.05]$ and $5[\mathrm{t}=7.78, P \leq 0.05]$. Repeated measures ANOVA showed significant differences between Naringin treated groups and $\mathrm{Al}+\mathrm{S}$ treated group [factor drug treatment: $\mathrm{F}(4,140)=8.12, P \leq 0.05]$.

\section{Time required ending task in maze}

The effect of naringin on working memory based on ending the task in the maze was depicted in Figure 2. The results showed a significant differences in between groups which were analysed by the one-way ANOVA $[\mathrm{F}(5,42)=6.65, P \leq 0.05] . \mathrm{Al}+\mathrm{S}$ treated group has showed significantly increased mean time in ending the task compared to control group [ $\mathrm{t}=6.12, P \leq 0.05]$. In contrast naringin treated groups has shown a

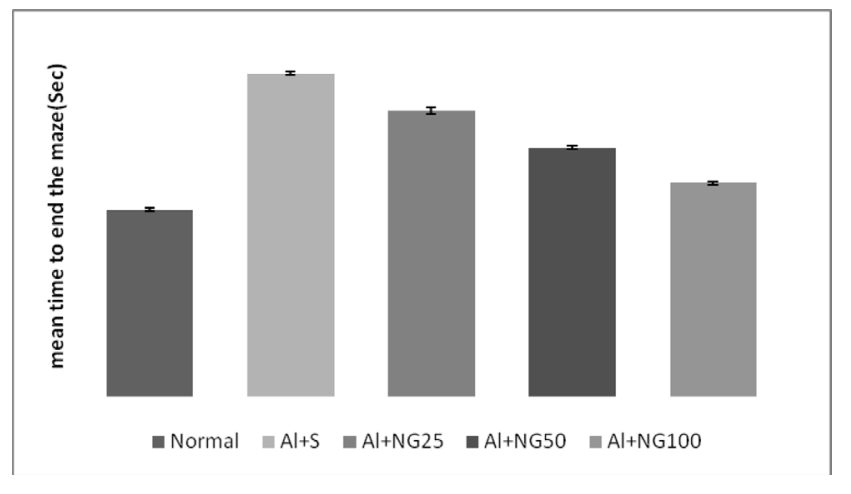

Figure 2: Effects of Naringin $(25,50$ and100 mg/kg) on mean time to end the task in radial arm maze against aluminum intoxication.

All values expressed mean \pm S.E.M. $P \leq 0.05, \mathrm{a}=\mathrm{Al}+\mathrm{S}$ Vs Normal, $\mathrm{b}=\mathrm{Al}+\mathrm{NG} 25 \mathrm{Vs}$ $\mathrm{Al}+\mathrm{S}, \mathrm{c}=\mathrm{Al}+\mathrm{NG} 50 \mathrm{Vs} \mathrm{Al}+\mathrm{S}, \mathrm{d}=\mathrm{Al}+\mathrm{NG} 100 \mathrm{Vs} \mathrm{Al}+\mathrm{S} . \mathrm{NG}=$ Naringin, $\mathrm{S}=\mathrm{Saline}$, $\mathrm{Al}=$ Aluminum

significant reduction in time required to end the task in maze when compared to $\mathrm{Al}+\mathrm{S}$ treated group.

\section{Role of naringin in Rota-rod test}

As demonstrated in Figure 3, the groups didn't varied significantly in terms of time required to fall from rota rod. This results were analysed by one-way ANOVA $[\mathrm{F}(5,42)=2.11, P \geq 0.05]$.

\section{Role of naringin on AChE activity}

Effect of naringin on brain AChE activity was demonstrated in Table 3. The results shown that there was a significant increase in AchE levels among $\mathrm{Al}+\mathrm{S}$ rats $[181.3 \pm 2.525, P \leq 0.05]$ when compared to control rats 


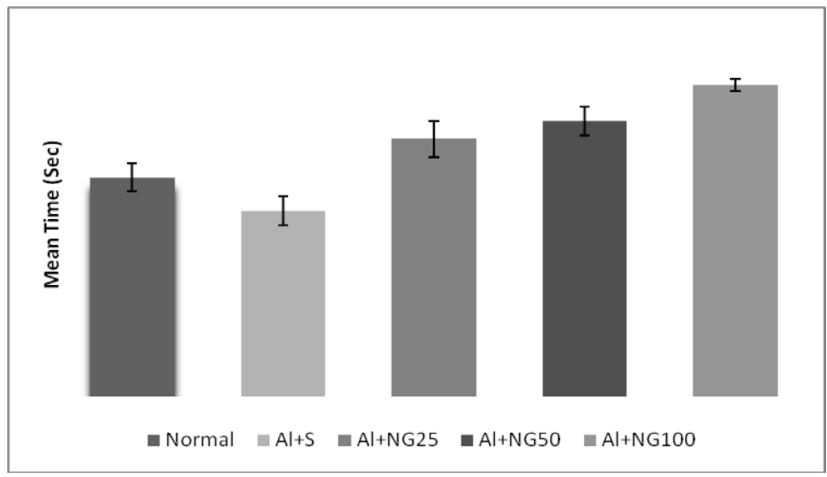

Figure 3: Effect of naringin on Rota rod test aginsist aluminum intoxication rats.

All values expressed mean \pm S.E.M. $P>0.05$, No significance difference, $\mathrm{NG}=$ Naringin, $\mathrm{S}=$ Saline, $\mathrm{Al}=$ Aluminum

\begin{tabular}{|c|c|}
$\begin{array}{c}\text { Table 3: Effect of Naringin on Acetylcholine esterase } \\
\text { activity against aluminum intoxication rats. }\end{array}$ \\
\hline Groups & $\begin{array}{c}\text { AchE } \\
\text { moles/min/gm tissue }\end{array}$ \\
\hline Normal & $105.3 \pm 1.667$ \\
\hline Al+S & $181.3 \pm 2.525^{*}$ \\
\hline Al+NG $25 \mathrm{mg} / \mathrm{kg}$ & $141.5 \pm 2.964^{*}$ \\
\hline Al+NG $50 \mathrm{mg} / \mathrm{kg}$ & $112 \pm 3.088^{*}$ \\
\hline Al+NG $100 \mathrm{mg} / \mathrm{kg}$ & $91.33 \pm 3.18^{*}$ \\
\hline Al+ Donepezil $0.75 \mathrm{mg} / \mathrm{kg}$ & $91.33 \pm 3.18$ \\
\hline
\end{tabular}

Data represent the mean $\pm \mathrm{SEM}$, the asterisk indicates $P \leq 0.05$, No of animals used in each group $=6$. $N G=$ Naringin, $A l=A l u m i n u m, ~ S=$ Saline

\begin{tabular}{|c|c|c|c|c|c|c|}
\hline \multicolumn{7}{|c|}{ Table 4: Effect of Naringin on oxidative markers in Aluminum Intoxication rats. } \\
\hline ASSESMENTS & NORMAL & Al+S & Al+NG25 & Al+ NG50 & Al+ NG100 & Al+ Donazapil \\
\hline $\begin{array}{c}\text { MDA } \\
\text { (nMol/gm of wet tissue) }\end{array}$ & $181.5 \pm 2.287$ & $636.3 \pm 3.902$ & $361.8 \pm 71.67^{*}$ & $341.00 \pm 11.85$ & $233.7 \pm 5.919$ & $217.9 \pm 3.64$ \\
\hline $\begin{array}{c}\text { SOD } \\
\text { (Units/mg of protein) }\end{array}$ & $9.372 \pm 0.356$ & $3.607 \pm 0.1439$ & $5.223 \pm 0.1628^{*}$ & $7.923 \pm 0.1653$ & $9.477 \pm 0.203^{*}$ & $8.985 \pm 0.2599$ \\
\hline $\begin{array}{c}\text { CAT } \\
\text { (Units/mg of protein) }\end{array}$ & $110.9 \pm 3.225$ & $27.00 \pm 0.7948$ & $39.00 \pm 1.005^{*}$ & $84.17 \pm 0.9627$ & $98.83 \pm 2.501^{*}$ & $93.82 \pm 3.873$ \\
\hline
\end{tabular}

Data represent the mean $\pm S E M$, the asterisk indicates $P \leq 0.05$, statistically significant difference from control group, MDA indicates Malondialdehyde, SOD indicates

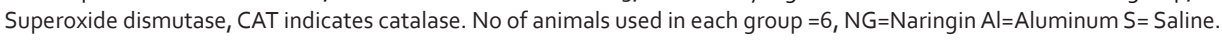

$[105.3 \pm 1.667]$. However, the AchE activity was significantly reduced in naringin $(25,50$ and $100 \mathrm{mg} / \mathrm{kg})$ treated groups $141.5 \pm 2.964,112 \pm 3.088,91.33 \pm 3.18$, $P \leq 0.05$ respectively compared to $\mathrm{Al}+\mathrm{S}$ rats. Moreover naringin $(100 \mathrm{mg} / \mathrm{kg})$ treated rats has shown decreased AchE levels $(91.33 \pm 3.18)$ in comparison with donezapil treated rats $(98.33 \pm 2.28)$.

\section{Role of naringin on oxidative stress}

SOD, MDA and CAT levels in the brain were quantified to evaluate the oxidative stress. The levels of MDA were significantly increased with significantly decreased SOD, CAT levels in $\mathrm{Al}+\mathrm{S}$ rats $[636.3 \pm 3.902,3.607 \pm 0.1439$, $27.00 \pm 0.7948, P \leq 0.05]$ when compared to control group. Further, significantly reduced MDA levels and increased SOD and CAT levels were observed in naringin $(25,50$ and $100 \mathrm{mg} / \mathrm{kg})$ treated rats when compared to $\mathrm{Al}+\mathrm{S}$ rats. These results were shown in Table 4.

\section{DISCUSSION}

Naringin activity against impaired cognitive and locomotors functions in aluminum intoxication rats was investigated in this study. Rats are exposing to $\mathrm{Al}$ for long term which leads to accumulation in brain, especially in the hippocampus. It is the learning and memory center. Al intoxication alters endogenous antioxidant enzyme activity and neuronal apoptosis. ${ }^{21,22}$ When it encountered with brain cells, cholinergic deficits will occurs that are reduced mRNA muscarinic receptors expressions, change in cholinesterase activity, degeneration of cholinergic terminals in hippocampus and decreased neuronal choline uptake. ${ }^{23,24}$ Contemporarily, several researchers focus on natural antioxidants, in particularly plant derived poly-phenolic compounds with neuroprotective potential ${ }^{25-27}$ and also reported the bio applicable properties of naringin, like anti-cancer, antioxidant, anti-inflammatory, cardiovascular protection and neuro protective effects. ${ }^{28-30}$

In our study, we observed that the rats with $\mathrm{Al}$-exposure for 60 days did not gain weight when we compared to control rats. Also, we clearly noticed the performance in food searching behavior of animals which are treated 
with $\mathrm{Al}$ for 60 days did not have a significant difference when we compare with control group. Thus, this findings supports that, $\mathrm{Al}$ does not decrease in motivation for food when the animals were subjected to trails for the learning the experiment. ${ }^{31,32} \mathrm{In} \mathrm{Al}$ treated rats, the time required to finish the task was significantly increased in comparison with the control group, this may be due to exploring more wrong arms before finish the task. Therefore, the animals' performance might be declined typically due to impairment in memory function rather than being related to decrease in motivation for food consumption in radial arm maze tests. ${ }^{33}$

In the open field test, $\mathrm{Al}$ treated group rats performance was not improved significantly in comparison to control group with repetitive administration of trials that undoubtedly reflected the $\mathrm{Al}$-induced impairment in spontaneous locomotive capacity, exploratory behavior, memory and learning. ${ }^{34}$ Rota-rod test is usually used to assess the motor function, fortitude and balance of muscle. In the experiment, we noticed that there is no significant alteration of motor performance in $\mathrm{Al}$ treated rats. These results implicate the effect of $\mathrm{Al}$ precisely on cognitive decline rather than alterations in motor function in rats. ${ }^{31}$

The significant results obtained from the eight arm radial maze and water morris maze tests that were demonstrated the potential effects of naringin in inverting the cognitive decline with the improved performance in intoxicated rats. The exploratory behavior and locomotors activity of naringin treated rats in open field test were improved significantly than $\mathrm{Al}$ treated. These results were in accordance with earlier reports. ${ }^{8}$ Recently, some of the studies also demonstrated the significant cognitive impairment was caused by chronic exposure of $\mathrm{Al}$ in the rats. ${ }^{2,3}$ Chronic administration of $\mathrm{Al}$ decreased the spontaneous locomotors activity and exploratory activity without any significant collision on motor coordination. ${ }^{31,33}$ In this experiment, we noticed the naringin treated rats had a significant reduction in the escape latencies during both hidden and visible platform sessions when compared to $\mathrm{Al}$ treated rats.

In comparison with $\mathrm{Al}$ treated rats, there was a significant improvement among naringin treated rats in the aspect of working and reference memories by ending their missions faster as demonstrated by radial arm maze test. It was found that chronic $\mathrm{Al}$ intoxication can decline reference and working memory. ${ }^{35}$ Therefore, in passive avoidance test, naringin was thought to improve the performance of Al-intoxicated rats as it increased the step-through latency significantly. This indicates that naringin treated animals were able to repossess and keep hold of the information. Even though, the fecal balls were significantly increased in the rats treated with large dose of naringin $(100 \mathrm{mg} / \mathrm{kg} /$ day), the latency to kick off movement was not changed significantly because of naringin didn't affect anxiety in $\mathrm{Al}$ treated rats. This can be explained by naringin mediated peripheral acetylcholine esterase activity.

Acetylcholine (Ach) is a key factor in learning and memory functions of brain. AChE enzyme degrades the Ach and terminates its action. In addition, the onset of few neurodegenerative diseases was involved with AChE enzyme. ${ }^{7}$ Chronic exposure of naringin $(25 \mathrm{mg} / \mathrm{kg}$ ) produces a minimal effect on the performance of rats in the redial and water maze tasks; while in large dose $(100 \mathrm{mg} / \mathrm{kg})$ formed its maximum responses. The cholinergic system plays an active role in several physiological processes like learning, memory and synaptic plasticity. ${ }^{36,37}$ To understand exact mechanisms of Alzheimer, the activity of brain AChE was determined. The results showed that levels of AChE were increased significantly in chronic Al-exposed rats. The cholinergic neurotransmission disruptions observed in this study can be correlated with behavioral impairments in the $\mathrm{Al}$ exposed rats. $\mathrm{AChE}$ levels were significantly reduced in chronic naringin exposed rats suggesting the naringin activity against AchE. These findings were in accordance with the earlier reports. ${ }^{8,38}$ Dose dependent effect of naringin was expressed in terms of AChE activity resulting as the levels of $\mathrm{AChE}$ is inversely proportional to the dose. Therefore, chronic supplementation of naringin clearly alleviated the AChE enzyme in the. This demonstrates the protective effects of naringin against the aluminum intoxication.

Oxidative stress is one of the major risk factor in Alzheimer disorder. Aluminum induced oxidative stress mechanism destructs the physiological antioxidant/ pro oxidant turmoil in favor of ROS generation. ${ }^{39-41} \mathrm{Al}$ may bind with superoxide anions and form $\mathrm{Al}$-superoxide anions and these oxidants can lead to reduced activity of mitochondrial superoxide dismutase. $^{4,6}$ In the $\mathrm{Al}$ treated rats, significantly increased MDA level and decreased CAT, SOD activities were noticed. Further, chronic supplementation of naringin significantly enhanced the antioxidant enzyme activity (SOD, CAT) and reduced the level of MDA. The protective activity of naringin on neurodegenerative disorders was advanced by the reduced activity of brain AChE enzyme and lipid peroxidation. 


\section{CONCLUSION}

This study demonstrates that $\mathrm{Al}$ treated rats were associated with behavioral changes and cognitive deficits. Naringin reverse these deficits at dose dependent manner. Therefore, we conclude that naringin had a protective role in the aluminum-induced deficits in the brain which is mostly related to oxidative stress and cholinergic dysfunction.

\section{ACKNOWLEDGEMENT}

The authors express their gratitude to GITAM Institute of Pharmacy for timely support in accomplishment of this study.

\section{CONFLICT OF INTEREST}

The authors declare that they have no conflict of interest.

\section{ABBREVIATIONS}

Al: Aluminium; ROS: Reactive oxygen species; SOD: Superoxide Dismutase; CAT: Catalase; AChE: Acetylcholinesterase; MDA: Malondialdehyde.

\section{REFERENCES}

1. Verma SS, Ranawat P, Nehru B. Modulatory Effects of Ginkgo biloba Against Amyloid Aggregation Through Induction of Heat Shock Proteins in Aluminium Induced Neurotoxicity. Neurochem Res. 2020;45:465-90.

2. Khalifa M, Safar MM, Abdelsalam RM, Zaki HF. Telmisartan Protects Against Aluminum-Induced Alzheimer-like Pathological Changes in Rats. Neurotox Res. 2020;37(2):275-85.

3. Liu H, Zhang W, Fang Y, Yang H, Tian L, Li K, et al. Neurotoxicity of aluminum oxide nanoparticles and their mechanistic role in dopaminergic neuron injury involving p53-related pathways. J Hazard Mater. 2020;392:122312.

4. Zhang J, Huang W, Xu F, Cao Z, Jia F, Li Y. Iron Dyshomeostasis Participated in Rat Hippocampus Toxicity Caused by Aluminum Chloride. Biol Trace Elem Res. 2019;1. doi: 10.1007/s12011-019-02008-7.

5. Sánchez-Muniz FJ, Macho-González A, Garcimartín A, Santos-López JA, Benedi J, Bastida S, et al. The Nutritional Components of Beer and Its Relationship with Neurodegeneration and Alzheimer's Disease. Nutrients. 2019;11(7):E1558.

6. Exley C. The pro-oxidant activity of aluminum. Free Radic Biol Med. 2004;36(3):380-7.

7. Zahoor M, Bari WU, Zeb A, Khan I. Toxicological, anticholinesterase, antilipidemic, antidiabetic and antioxidant potentials of Grewia optiva Drummond ex Burret extracts. Journal of Basic and Clinical Physiology and Pharmacology. 2020;31(2):1-16.

8. Kakkar V, Kaur IP. Evaluating potential of curcumin loaded solid lipid nanoparticles in aluminium induced behavioural, biochemical and histopathological alterations in mice brain. Food Chem Toxicol. 2011;49(11):2906-13.

9. Rodriguez MMA, Butler ED, Rodriguez HA, Wilson CF, Anderson O, Gustafson JP. Expressed sequence tag-based gene expression analysis under aluminum stress in rye. Plant Phys. 2002;130(4):1-11.

10. Zafar $\mathrm{R}$, Ullah $\mathrm{H}$, Zahoor $M$, Sadiq $A$. Isolation of bioactive compounds from Bergenia ciliata (Haw.) Sternb rhizome and their antioxidant and anticholinesterase activities. BMC Complementary and Alternative Medicine. 2019;19(1):296.
11. Johnson GV, Jope RS. Aluminum impairs glucose utilization and cholinergic activity in rat brain in vitro. Toxicology. 1986;40(1):93-102.

12. Naz S, Zahoor M, Umar MN, Ali B, Ullah R, Shahat AA, et al. Enzyme inhibitory, antioxidant and antibacterial potentials of synthetic symmetrical and unsymmetrical thioureas. Drug Design, Development and Therapy. 2019;13:3485-95.

13. Alam MA, Subhan N, Rahman MM, Uddin SJ, Reza HM, Sarker SD. Effect of Citrus Flavonoids, Naringin and Naringenin, on Metabolic Syndrome and Their Mechanisms of Action. Adv Nutr. 2014;5(4):404-17.

14. Hassaan $\mathrm{Y}$, Handoussa H, El-Khatib AH, Linscheid MW, ElSayed N, Ayoub N. Evaluation of plant phenolic metabolites as a source of Alzheimer's drug leads. Biomed Res Int. 2014;2014:843263.

15. Bharti S, Rani N, Krishnamurthy B, Arya DS. Preclinical evidence for the pharmacological actions of naringin: A review. Planta Med. 2014;80(6):437-51.

16. Cui QJ, Wang LY, Wei ZX, Qu WS. Continual naringin treatment benefits the recovery of traumatic brain injury in rats through reducing oxidative and inflammatory alterations. Neurochem Res. 2014;39(7):1254-62.

17. Ellman GL, Courtney KD, JrAndres V. Feather-Stone RM, A new and rapid colorimetric determination of acetylcholinesterase activity. Biochem Pharmacol. 1961;39(7):88-95.

18. Okhawa H, Ohishi N, Yagi K. Assay of lipid peroxides in animals tissue by thiobarbituric acid reaction. Anal Biochem. 1979;95(2):351-8.

19. Kakkar P, Das B, Viswanathan PN. A modified spectrophotometric assay of superoxide dismutase. Ind J Bio Chem Biophys. 1984;21:130-2.

20. Aebi H. Catalase: Methods in enzymatic analysis (ed.H.U.Bergmer). 1974;2:673-84.

21. Onyango IG, Bennett JP, Tuttle JB. Endogenous oxidative stress in sporadic Alzheimer's disease neuronal cybrids reduces viability by increasing apoptosis through pro-death signaling pathways and is mimicked by oxidant exposure of control cybrids. Neurobiol Dis. 2015;19(1-2):312-22.

22. Shi Q, Gibson GE. Oxidative stress and transcriptional regulation in Alzheimer disease. Alzheimer Dis Assoc Disord. 2007;21(4):276-91.

23. Babic T. The cholinergic hypothesis of Alzheimer's disease: A review of progress. J. Neurol. Neurosurg Psychiatry 1999;67(4):558.

24. Kar S, Slowikowski SP, Westaway D, Mount HT. Interactions between beta-amyloid and central cholinergic neurons: implications for Alzheimer's disease. J Psychiatry Neurosci. 2004;29:427-41.

25. Moosmann B, Behl C. Antioxidants as treatment for neurodegenerative disorders. Expert Opin Investig Drugs. 2002;11(10):1407-35.

26. Rao AV, Balachandran B. Role of oxidative stress and antioxidants in neurodegenerative diseases. Nutr Neurosci. 2002;5(5):291-309.

27. Orhan IE, Suntar IP, Akkol EK. In vitro neuroprotective effects of the leaf and fruit extracts of Juglans regia L. (walnut) through enzymes linked to Alzheimer's disease and antioxidant activity. Int J Food Sci Nutr. 2011;62(8):781-6.

28. Tan TW, Chou YE, Yang WH, Hsu CJ, Fong YC, Tang CH. Naringin suppress chondrosarcoma migration through inhibition vascular adhesion molecule-1 expression by modulating miR-126. Int Immunopharmacol. 2014;22(1):107-14.

29. Li H, Yang B, Huang J, Xiang T, Yin X, Wan J, et al. Naringin inhibits growth potential of human triple-negative breast cancer cells by targeting $\beta$-catenin signaling pathway. Toxicol Lett. 2013;220(3):219-28.

30. Benavente-Garcia O, Castillo J. Update on uses and properties of citrus flavonoids: New findings in anticancer, cardiovascular and anti-inflammatory activity. J Agric Food Chem. 2008;56(15):6185-205.

31. Abdel-Aal RA, Assi AA, Kostandy BB. Rivastigmine reverses aluminuminduced behavioral changes in rats. Eur J Pharmacol. 2011;659(2-3):169-76.

32. Golub, MS, Germann SL. Aluminum effects on operant performance and food motivation of mice. Neurotoxicol Teratol. 1998;20(4):421-7.

33. Abdel-Aal RA, Assi AA, Kostandy BB. Memantine prevents aluminuminduced cognitive deficit in rats. Behav Brain Res. 2011;225(1):31-8.

34. Filali M, Lalonde R, Theriault P, Julien C, Calon F, Planel E. Cognitive and non-cognitive behaviors in the triple transgenic mouse model of Alzheimer's disease expressing mutated APP, PS1 and Mapt (3xTg-AD). Behav Brain Res. 2012;234(2):334-42.

35. Abu-Taweel GM, Ajarem JS, Ahmad M. Neurobehavioral toxic effects of perinatal oral exposure to aluminum on the developmental motor reflexes, learning, memory and brain neurotransmitters of mice offspring. Pharmacol Biochem Behav. 2012;101(1):49-56. 
36. Marina RP, Michael JH, Yann SM. Acetylcholine as a neuromodulator: Cholinergic signaling shapes nervous system function and behavior. Neuron. 2012;76(1):16-129.

37. Palotai M, Telegdy G, Bagosi Z, Jászberényi $M$. The action of neuropeptide AF on passive avoidance learning. Involvement of neurotransmitters. Neurobiol Learn Mem 2016;127:34-41.

38. John J, Nampoothiri M, Kumar N, Mudgal J, Nampurath GK Chamallamudi MR. Sesamol, a lipid lowering agent, ameliorates aluminium chloride induced behavioral and biochemical alterations in rats. Pharmacogn Mag. 2015;11(42):327-36.
Sharma DR, Wani WY, Sunkaria A, Kandimalla RJ, Verma D, Cameotra SS et al. Quercetin protects against chronic aluminum-induced oxidative stress and ensuing biochemical, cholinergic and neurobehavioral impairments in rats. Neurotox Res. 2013;23(4):336-57.

40. Bymaster FP, Heath I, Hendrix JC, Shannon HE. Comparative behavioral and neurochemical activities of cholinergic antagonists in rats. J Pharmacol Exp Ther. 1993;267(1):16-24

41. Mattson $\mathrm{RH}$. Cognitive, affective and behavioral side events in adults secondary to antiepileptic drug use. Rev Neurol Dis. 2004;1(Suppl 1):10-7.

\section{PICTORIAL ABSTRACT}

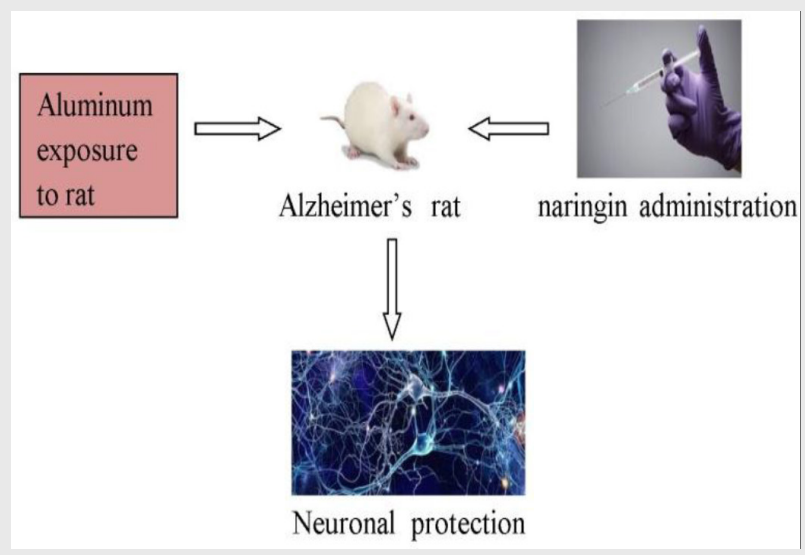

\section{SUMMARY}

The effects of aluminum on the cognition and development of Alzheimer's has been demonstrated. The positive effect of naringin in Alzheimer's through reducing the oxidative stress and acetylcholine esterase activity has been reported. The improvement of cognition among aluminum induced alzheimer's by naringin has been reported.

\section{About Authors}

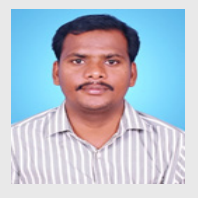

Dr. Orsu Prabhakar working as an Assistant Professor In GITAM Institute of Pharmacy, GITAM Deemed to be University. He had extensive research and teaching experience in the field of Pharmacology and Toxicology.

Cite this article: Prabhakar O. Naringin Attenuates Aluminum Induced Cognitive Deficits in Rats. Indian $\mathrm{J}$ of Pharmaceutical Education and Research. 2020;54(3):674-81. 